\title{
International Air Carriage Liability
}

Bohumil Poláček*

\begin{abstract}
Air carriage liability for damage represents an essential issue of national and international transport, therefore it is regulated by national law (this article emphasizing Czech law), EU law and international law. Czech regulation consists of provisions of the Civil Code and the Aviation Act, mainly concerning operator's liability. Several key Regulations, representing EU law, cover many aspects, for example compensation and assistance to passengers in the event of denied boarding and of cancellation or long delay of flights. The Montreal Convention introduced two tiers of liability and the fifth jurisdiction.
\end{abstract}

\section{Keywords}

Air Carrier; Liability; Operator of Transport; Compensation; Montreal Convention.

\section{Introduction}

Air carrier liability for damage must be perceived from several angles. National legal regulation is the fundamental one, represented by the Civil Code, specifically provisions of Articles 2927 to 2932, and the Aviation Act in the Czech Republic. ${ }^{1}$ European Union legislation presents an angle of another level. There is Council Regulation (EC) No 2027/97 on air carrier liability in the event of accidents, amended by Regulation (EC) No 889/2002, and Regulation (EC) No 261/2004 establishing common rules on compensation and assistance to passengers in the event of denied boarding and of cancellation or long delay of flights. (We may also take into account an upcoming amendment - Proposal for a Regulation amending Regulation (EC) No 261/2004 and Regulation (EC) No 2027/97). International treaties constitute the third group. There is the Warsaw Convention, amended

\footnotetext{
* Doc. JUDr. Ing. Bohumil Poláček, Ph.D., MBA, LLM, Ekonomická fakulta, Technická univerzita v Liberci / Faculty of Economics, Technical University of Liberec, Czech Republic / E-mail: bohumil. polacek@tul.cz

1 Act No 49/1997 on civil aviation amending Act No 455/1991 on trade business (Trade Act), as amended.
} 
by the Hague Protocol ${ }^{2}$ [the Guatemala City Protocol (1971) and the four Montreal Protocols (1975)] ${ }^{3}$, the Guadalajara Convention and the Montreal Convention. ${ }^{4}$

Legal regulation created by the Warsaw Convention is complemented by a document by the IATA, ${ }^{5}$ an international non-governmental organization - the IATA General Conditions of Carriage (1957 and 1971), ${ }^{6}$ the Montreal Agreement (1966) ${ }^{7}$ for its adherence by the United States and Canada and the Malta Agreement (1976) for several European airlines. The Agreements increase maximum liability limitations

2 Act No 243/1933 on the Convention for the Unification of Certain Rules Relating to International Carriage by Air and its Additional Protocol coming into effect, as amended by Act No 15/1935, the Convention for the Unification of Certain Rules Relating to International Carriage by Air, and by Decree of Minister of Foreign Affairs No 15/1966 on the Protocol amending the Convention for the Unification of Certain Rules Relating to International Carriage by Air, signed at Warsaw on 12 October 1929.

3 The Guatemala City Protocol made the liability system stricter, introducing a significant increase of liability limitations of a carrier and the fifth jurisdiction apart from other things. The Montreal Protocol No. 1 amends the Warsaw Convention and converts the limits of liability into SDRs. The Montreal Protocol No. 2 amends the Warsaw Convention as amended at the Hague 1955 and converts the limits of liability into SDRs. The Montreal Protocol No. 3 amends the Warsaw Convention as amended at the Hague 1955 and converts the limits of liability into SDRs. The Montreal Protocol No. 4 amends the Warsaw Convention as amended at the Hague 1955, converts the limits of liability into SDRs and amends liability of a carrier in international carriage of cargo. Neither the Guatemala City Protocol nor the Montreal Protocol No. 3 have come into force. The Czech Republic is not a contracting party to any of the Protocols.

Available at:

http://www.icao.int/secretariat/legal/List $\% 20$ of $\% 20$ Parties/Guatemala_EN.pdf

http://www.icao.int/secretariat/legal/List \%20of\%20Parties/AP1_EN.pdf

http://www.icao.int/secretariat/legal/List $\% 20$ of $\% 20$ Parties/AP2_EN.pdf

http://www.icao.int/secretariat/legal/List $\% 20$ of $\% 20$ Parties/AP3_EN.pdf

http://www.icao.int/secretariat/legal/List\%20of\%20Parties/MP4_EN.pdf

4 A list of multilateral treaties available at: http://www.icao.int/secretariat/legal/Lists/Current $\% 20$ lists $\% 20$ of $\% 20$ parties/AllItems.aspx

5 The International Air Transport Association.

6 IATA General Conditions of Carriage.

The current version available at: http://www.transportrecht.de/transportrecht_content/1145517747.pdf Conditions of Carriage by the Czech Airlines (ČSA) available at: https://www.csa.cz/cz-en/ travel-information/before-the-flight/conditions-of-carriage/

7 Agreement Relating to Liability Limitations of the Warsaw Convention and the Hague Protocol. It is a bilateral treaty between the USA and individual air carriers, in which the carriers undertake to increase limits of compensation (for example, 75000 USD in case of death). The carrier is liable for damage from boarding to disembarking, even if it proves it took all reasonable measures to avoid damage. Therefore, it changes a concept of strict liability of a carrier to absolute liability of a carrier.

Available at: http://scholarlycommons.law.northwestern.edu/cgi/viewcontent.cgi?article $=1182$ $\&$ context $=$ njilb

8 In the context of adopting the Montreal Agreement, many Western European airlines undertook to increase liability limitations in case of death to 58000 USD even for their other flights. See GIEMULLA, E. M. and L. WEBER. International and EU Aviation Law. Selected Issues. Alphen aan den Rijn: Wolters Kluwer International, 2011, p. 250. 
of a carrier.' The IATA also adopted the Intercarrier Agreement on Passenger Liability in $1995 .^{10}$

\section{Air carriage liability under national law}

Air carrier liability is regulated by the Czech Civil Code in Book Four (Relative property rights), Title Three (Obligations arising from torts), Division Two (Duty to provide compensation for damage), Subdivision Two (Special provisions), Sections 2927 to 2932 (Damage caused by operation of a means of transport) and by the Aviation Act in Section 25b, Section 68 and Section 85n in our legal system.

\subsection{Operator's liability ${ }^{11}$}

The purpose of regulation is to have a preventive effect on an operator to keep means of transport in condition to minimize danger of a loss event (operators are motivated to comply with technical and safety regulations) and to ensure easier enforcement of victim's rights, because a tortfeasor has a significantly limited opportunity to be released from a duty to compensate. The stricter burden on the tortfeasor is driven by an effort to penalize more a person having benefit from such an enterprise, i.e. the operator of transport or of a vehicle. ${ }^{12}$

Special regulation of a duty to compensate for damage caused by operation of an aircraft is not a lex specialis in relation to a duty to compensate for damage caused by breaching a statute, but they can exist simultaneously, mainly because both types impact on different persons. An operator's duty does not arise out of breaching an obligation and is not fault-based. It arises if there was a causal link between damage and specially qualified circumstances, which are presented by specific nature of operation of an aircraft. ${ }^{13}$ Under this provision, the duty to compensate for damage is not imposed on the person directly involved in the accident, but on the operator of transport or an aircraft. The statute

9 KRETSCHMER, N. Das Internationale Privatrecht der zivilen Verkehrsluftfahrt, Schriften zum Internationalen und vergleichenden Privatrecht. Frankfurt: Peter Lang, 2003, p. 51.

10 Intercarrier Agreement on Passenger Liability. It introduced a stricter system of liability of a carrier regarding higher limitations and strict liability if an air carrier includes it into its conditions of carriage.

11 See Section 2927 of the Civil Code: „(1) A person who operates transport shall compensate the damage caused by specific nature of such operation. Another operator of a vehicle, vessel or aircraft has the same duty, unless such a means of transport is driven by buman power. (2) An operator may not be released from the duty to compensate for the damage if the damage was caused by circumstances originating from operation. Otherwise, the operator is released from the obligation if he proves that he could not have prevented the damage despite having exerted all the efforts which may have been required."

12 See HULMÁK, M. a kol. Občanský quákoník. V1. Závazkové právo. Zvlástní cást (』 2055 až 3014) [The Civil Code IV. Obligations. Special part (Sections 2055 to 3014)]. Praha: C. H. Beck, 2014, pp. 1611-1612.

13 See ŠVESTKA, J., J. DVOŘÁK, J. FIALA a kol. Občanský qákoník. Komentár. Svazeke VI (relativni majetková práva) [The Civil Code. Commentary. Volume IV (Relative property rights)]. Praha: Wolters Kluwer, 2014, pp. 1014-1015. 
differentiates between two types of operators: a) a person which operates transport or carriage as his object of activities (operator of transport), and b) another operator (operator of an aircraft), which is another person who operates (not necessarily as a business enterprise) an aircraft, without this being a part of an organized transport business. ${ }^{14}$ The difference is that the operator of transport compensates for damage regardless of with what means of transport the transport was realized. The operator of a means of transport compensates for damage only if it was caused by operation of one of the enumeratively defined means of transport. In reality, a person can be defined as an operator of transport only if he operates transport in accordance with a special statute ${ }^{15}$ regulating the specific kind of transport. ${ }^{16}$ However, a person which operates transport without a corresponding authorization is also considered to be an operator of transport in order to be able to be a subject of penalization.

A person which has a legal and factual possibility have a means of transport at his disposal is considered to be the operator of such means of transport. The disposal is characterized mainly by a fundamentel function of the means of transport (flight), but also by its maintenance, paying operating costs, paying repairs etc. It is also possible to consider a lessee to be an operator, for instance, who holds a similar position to an owner of an aircraft (he uses it, pays the costs related to operation etc.), but he is not a proprietor until conditions of the lease are met. Use of the means of transport by the operator must be of long-term nature. ${ }^{17}$

Specific nature of operation, ${ }^{18}$ which is not legally defined in any way, is used as the foundation because operation of an aircraft is a source of an increased potential

14 ŠVESTKA, DVOŘÁK, FIALA a kol., 2014, op. cit., p. 1015-1016.

15 In our case Act No 49/1997 on civil aviation amending Act No 455/1991 on trade business (Trade Act), as amended.

16 HULMÁK, 2014, op. cit., p. 1613.

17 HULMÁK, 2014, op. cit., p. 1614.

18 Case law:

An injury originating in an accident of an ultralight aircraft during a sigbtseing flight [Section 24(1)(e) of Decree No 108/1997] at time of landing is damage caused by specific nature of operation of a means of transport as in a provision of Section 427(2) of the Civil Code. (Rc 15/08)

If victim's fault was the sole cause of damage occasioned by specific nature of operation of a means of transport, the operator is released from liability fully and the victim bears damage in its entirety. (NS 25 Cdo 2800/2007)

Liability for damage caused by operation of a means of transport is judged in accordance with Section 427 of the Civil Code, only if damage is caused by specific nature of operation of the means of transport, not if damage was caused by a breach of an obligation in relation to operation of the mean of transport not caused by nature of such operation. (Rc 20/75)

If damage was caused by circumstances originating in operation, the operator cannot be released from liability, not even by pointing out an inevitable act of a third person. (Rc 16/69)

Deficiency or defects of materials, although concealed, belong among circumstances originating in operation. The operator cannot be released from liability for damage thus caused as damage originating in operation. (Rc 9/72)

An operator is always liable for damage caused as a result of failure or deficiency of organisms of persons used in operation; he is liable for damage originating in technical condition of a used means of transport as well. Exerting all the efforts means to take every possible precautions under given conditions of a specific case to prevent damage; inevitability means impossibility to prevent damage by any provision at the current state and development of technology. Inevitable damage may originate in naturalphenomena (a lighning, a flood, an earthquake etc.) or in human conduct or in animal behaviour. Damage must be objectivelly inevitable, meaning no operator could prevent such damage under given circumstances, not just the specific operator. (Rc 3/84) 
of damage to human health and property, as it is an technical activity linked to motoric power, fast movement and use of increasingly sophisticated methods and techniques of traffic control that do not eliminate failure. Therefore, unlike a duty to compensate for damage caused by a breach of a statute, the operator is obliged to compensate for damage not only if an adverse effect of an aircraft was linked to a breach of a statute, but also if specific nature of operation was manifested, i.e. an undesirable display of characteristics typical for such operation occured and arised from its nature as a means of transport, which usually moves by motoric power at increased speed and is able to have only by its movement an adverse effect on persons inside the aircraft or persons or objects (property) coming in contact with it. Operation means not only movement of an aircraft, but also preparation and immediate operation after completion, including disembarking. ${ }^{19}$

There is a reason of liberation available for an operator. He can be released from the duty if he proves that he could not have prevented the damage despite having exerted all the efforts which may have been required. Accoding to not very frequent case law, it is considered to be an objective category, measured particularly by the current level of technology, that is generally in relation to every possible operator depending on how it is possible to prevent such event, not an subjective assessment considering specific circumstances. The reason of liberation is thus met either by an unavoidable event as an outside intervention (e.g. natural phenomena, intervention from a third person or an animal), which caused the adverse effect during operation of an aircraft and which could not have been prevented by the operator in any way, or by an event connected to operation that could not have been prevented by any measures available. However, this does not apply if damage was caused by circumstances originating from operation; then it is not possible to invoke reasons that constitute the reason of liberation. The concept of circumstances originating from operation is narrower than the concept of specific nature of operation and it should indicate sources of danger conceptually connected to operation of transport or a means of transport, e.g. failure or deficiency in actions of persons involved in operation, deficiency or defects of materials, including concealed ones, or technical condition of an aircraft. ${ }^{20}$

The notion of the reason of liberation does not exclude an application of general provisions concerning all types of duties of compensation for damage, including Section 2918 of the Civil Code, according to which if damage has been incurred, or if it has increased also as a result of circumstances attributable to the victim, the tortfeasor's duty to compensate for damage is proportionately reduced. A principle of casus sentit dominus ${ }^{21}$ is thus

19 ŠVESTKA, DVOŘÁK, FIALA a kol., 2014, op. cit., p. 1016.

20 ŠVESTKA, DVOŘÁK, FIALA a kol., 2014, op. cit., p. 1017.

21 An owner bears the risk of an accident (an owner compensates for damage caused by an accident, not a person who, without fault, caused it). 
fulfilled, the victim bears consequences of an accident which affected him. In such case it is exoneration from carrier liability not on the basis of the reason of liberation, but a lack of causal link between circumstances for which it is liable strictly and damage to the victim. ${ }^{22}$

\subsection{An operator while an aircraft is under repair ${ }^{23}$}

The operator's position is modified if it is not appropriate to prosecute the original operator in the way of this stricter type of duty for compensation. An operator of a repair shop is placed in the position of the operator of an aircraft thanks to legal fiction (,is considered" $).{ }^{24}$ There are two fundamental types of situation, the operator does not have the aircraft at his disposal, so the law delegates this duty to another person. Apart from i) a person who uses an aircraft without the knowledge or against the will of the operator, ${ }^{25}$ the position of an operator is imposed on ii) the operator of business undertaking repairing the aircraft, specifically during the repair period. This, in particular, covers damage caused by a test flight or while the aircraft is being prepared for reconnection. It must be a person repairing aircrafts as his business enterprise. ${ }^{26}$

It is irrelevant of what nature the repair is, which parts of the means of transport are concerned, which parts are changed, or how much time it takes. An inspection of the means of transport, during which no defects are removed, is also of nature of repair. It is not important why the aircraft was put into operation at the repair period (e.g. a test flight). The fact that damage ocurred between the takeover of the aircraft and its return to the operator is crucial. ${ }^{27}$

\subsection{Damage caused by theft or loss of a trasported thing ${ }^{28}$}

Trasported things may also be damaged during operation of an aircraft. If they are damaged or destroyed as a result of specific nature of operation (e.g. they are broken or burned), the operator or the person in his place compensates for damage. ${ }^{29}$ The law

22 ŠVESTKA, DVOŘÁK, FIALA a kol., 2014, op. cit., p. 1017-1018.

23 See Section 2928 of the Civil Code: „If a means of transport is under repair, the person who took over the means of transport for repair is considered to be its operator."

24 HULMÁK, 2014, op. cit., p. 1619.

25 See Section 2929 of the Civil Code.

26 ŠVESTKA, DVOŘÁK, FIALA a kol., 2014, op. cit., p. 1020.

27 HULMÁK, 2014, op. cit., p. 1620.

28 See Section 2931 of the Civil Code: „Where theft or loss of a thing results in damage being caused to a thing, the operator shall provide compensation for the damage only if the victim had no opportunity to keep the thing safe."

29 According to Sections 2928 and 2929 of the Civil Code in relation to Sections 2927 or 2932 of the Civil Code. 
especially remembers a situation if damage was caused by a thing being lost or stolen; ${ }^{30}$ the operator compensates for damage if the thing was transported in a way that the victim could not have it in his charge (the thing was transported separately), or he lost control due to the situation (a traffic accident or another complication). ${ }^{31}$

Compensation for damage by the operator should only occur if the victim did not have an opportunity to guard the thing and as the result of a loss event. The aim is to provide increased protection to the victim in a moment in which he is not able to take proper care of his property as a result of an injury and general chaos caused by the loss event. At the same time, the victim is released from the burden of ascertaining and proving if, how and by whom his thing was stolen. This rule is a special case of explicit confirmation of imputability of damage based on psychological causality - the loss event in the operator's sphere gave an opportunity for subsequent damage, therefore this damage is attributed to him as well. ${ }^{32}$

In the event of a victim being transported on the basis of a contract of carriage of a person, ${ }^{33}$ claims for compensation for damage to baggage are regulated by Section 2554 of the Civil Code, which, however, refers to provisions on compensation for damage caused operation of means of transport for things carried by a passenger. ${ }^{34}$ If a carrier transports a thing separately from the passenger, a provision contained in Section 2566 et seq. of the Civil Code, concerning carriage of a thing, is applied in accordance with Section 2554(2) of the Civil Code. ${ }^{35}$

\subsection{Settlement in the event of a collision of operations ${ }^{36}$}

A relation between operators and a manner of settlement between them in the event of a collision of their operations are regulated (a division rule). Operators' participation in causing total damage resulting from the collision is crucial; there are circumstances of the particular case which were the main causes of damage. These principles are only

30 Case law:

Regulation of strict liability of an air carrier for damage caused by loss of checked baggage in Art.17(2) of the Montreal Convention does not deal with a question of extent of damage or a method of its assessment. The burden of proof of origins and extent of damage rests with the plaintiff in a dispute over compensation for such damage. (NS 25 Cdo 4827/2008)

A fact that damage was caused by specific nature of operation is a condition for application of Section 427 et seq. of the Civil Code with regard to Section 764(1) of the Civil Code. A fact that damage took place in a means of transport during carriage does not mean that it is damage caused by specific nature of such operation. (NS ČSR 2 Cz 37/79, S IV, s. 618)

31 ŠVESTKA, DVOřÁK, FIALA a kol., 2014, op. cit., p. 1026.

32 HULMÁK, 2014, op. cit., p. 1623.

33 According to Section 2550 et seq. of the Civil Code.

34 See Section 2554(1) of the Civil Code.

35 ŠVESTKA, DVOř́́K, FIALA a kol., 2014, op. cit., p. 1026.

36 See Section 2932 of the Civil Code: ,Where operations of two or more operators collide and in the case of a settlement between the operators, the operators shall settle according to their contribution to the damage caused." 
applied when dealing with reciprocal claims between the operators, because if damage was caused to other persons, who are not operators, in a collision of operations, or to other persons (e.g. owners of immovable property damaged in an accident), the operators are liable. There is also a possibility of these persons damaging operators ${ }^{6}$ property. ${ }^{37}$

Motion of aircrafts is governed by detailed rules, therefore an evaluation of whether and how each of the participants respected these rules and whether and to what extent their eventual breach lead to the collision and adverse effects is a part of consideration of participation in the collision most of the times. In any case, in a dispute, a court must assess all circumstances related to the degree of participation of each of the participants, both in terms of a breach of an obligation and in terms of the adverse effect of nature of operation, irrespective of fault. Potential fault or omission of one (or some) of the operators also formulates an objective degree of participation, if a causal link leading to damage was established by it. Conversely, if there are such circumstances (including coincidence) or a conduct without a causal link to the adverse effect, the condition of participation in damage is not met and therefore neither liability nor reason for settlement arise. A fact that operations collided does not automatically mean that each of the operators has duty to compensate for damage. It is possible (it does not contradict the concept of strict liability in any way) that the result of comparison of participation of the individual operators lies in a conclusion that participation of one of them is so minimal that the duty to compensate for damage does not arise. ${ }^{38}$

The collision of operations ${ }^{39}$ is a key concept, it is a broader term than a collision of aircrafts, as they can affect each other differently than just by a direct collision or a similar direct contact. A collision of an aircraft and a piece of equipment of different operation (e.g. an airport tank) is also a collision of operations. There may not even be a direct contact. All forms of interactions may occur between all kinds of operations, of course,

37 ŠVESTKA, DVOŘÁK, FIALA a kol., 2014, op. cit., p. 1028.

38 ŠVESTKA, DVOŘÁK, FIALA a kol., 2014, op. cit., p. 1028.

39 Case law:

It is crucial to what extent individual circumstances participated in damage, respectively to what extent which cause participated in specific damage, for settlement of damage between operators in a collision of operations of means of transport. (NS 28 Cdo 1532/2006)

Assessing all circumstances of a collision, particularly those representing main causes of damage, is a condition for a settlement between participants of a collision of operations. Potential fault or omission of one of the operators also formulates an objective degree of participation, if a causal link leading to damage was established by it. Conversely, if there are such circumstances, conducts or omission without a causal link to an adverse effect, the lawful condition of participation in damage is not met and therefore neither liability nor reason for settlement arises. (NS 25 Cdo 566/2006)

A court is obliged to bave evidence presented that was not only suggested by parties, concerning not only a breach of an obligation, but ascertaining all circumstances of a collision for establishing the degree of participation of both operators in a dispute over compensation for damage in the collision of operations. (NS 25 Cdo 1948/2005)

It is possible that a comparison of participation of the individual operators lies in a conclusion that participation of one of them is so minimal that liability for damage does not arise. (NS 25 Cdo 238/2002) 
e.g. an emergency landing of an aircraft on a road or a highway. ${ }^{40}$ Therefore, the collision is not only a direct collision, but there may be a mere interaction of one operation with another without any direct physical contact ${ }^{41}$ (an aircraft may get into wake turbulence behind another plane and crash).

Coincidence presents quite significant circumstances which may influence the course of traffic and a subsequent collision as it affects an aircraft as another unforseen factor (a bird sucked into a turbojet). In accordance with a principle of casum sentit dominus the consequences of coincidence are borne by the person affected, hence even these accidental circumstances are assessed to the detriment of a person whose transport was affected when determining a degree of participation of the operators in a collision. ${ }^{42}$

The operators of collided means of transport settle on the basis of their participation in causing damage. It is not pivotal for establishing participation in the collision whether shares of the individual operators are fault-based. Damage may be caused, on the one hand, by negligence (or intent) of an operator and, on the other hand, by an objectively occuring event originating from another operator's operation (e.g. a technical defect). ${ }^{43}$

A third person may also participate in a collision of operations (as a victim or a tortfeasor). This third person's duty to compensate for damage arises from Section 2910 of the Civil Code as a general rule (an absolute right of the victim was affected). He becomes another tortfeasor apart from collided operators. Section 2916 of the Civil Code is applied for their mutual settlement (he settles with the operators according to participation in causing damage, i.e. according to the same rule as the operators among themselves). Regarding damage to this third person, the operators compensate such person for damage jointly and severally ${ }^{44}$ in accordance with Section 2927 of the Civil Code, in case of co-causing damage the torfeasor's duty to compensate for damage reduces proportionately. ${ }^{45,46}$

\subsection{Airport owner's liability}

An airport owner is obliged to ensure operation of the airport. If the airport owner is unable to ensure operation of the airport, he is obliged to offer the airport to the state for ensuring its operation. The airport owner submits a written offer to the Ministry of Transport within 60 days since he became aware of the fact referred to in the previous sentence, but no later than 60 days before the termination of airport operation,

\footnotetext{
40 ŠVESTKA, DVOŘÁK, FIALA a kol., 2014, op. cit., p. 1029.

41 HULMÁK, 2014, op. cit., p. 1624.

42 ŠVESTKA, DVOŘÁK, FIALA a kol., 2014, op. cit., p. 1030.

43 Srov. HULMÁK, 2014, op. cit., p. 1625.

44 According to Section 2915 of the Civil Code.

45 According to Section 2918 of the Civil Code.

46 Srov. HULMÁK, 2014, op. cit., p. 1625.
} 
if he is not also the operator of the airport. If it is required by the public interest, the Ministry of Transport ensures airport operation on the basis of a written agreement concluded with the airport owner for a period of time during which the airport owner is unable to ensure operation on his own or via another operator. ${ }^{47}$

\subsection{Domestic air carrier liability}

A domestic air carrier is obliged to i) operate commercial air transport under conditions set in a licence, ii) notify the Agency for Civil Aviation of any changes to the facts on the basis of which the licence was granted and of an identification number of a legal person, if not included in a licence application, or of changes concerning compliance with conditions set in the licence within 10 days since such changes emerged, iii) notify the Agency for Civil Aviation of commencement of regular commercial air transport for which it has a valid license at least 20 days in advance, iv) notify the Agency for Civil Aviation of commencement of irregular commercial air transport for which it has a valid license at least 3 days in advance, v) notify the Agency for Civil Aviation of suspension or termination of commercial air transport for which it has a valid license within 24 hours, vi) upon suspending its license, to ensure at its expense transport of persons, baggage, animals, cargo and mail which it has undertaken, vii) declare conditions of carriage on the date of commencement of commercial air transport.

In addition, the domestic air carrier is obliged to draw up and follow a plan of assistance to victims of aircraft accidents and their relatives. ${ }^{48}$ The plan of assistance to victims of aircraft accidents and their relatives includes i) operating procedures for confirming participation of passengers in an aircraft accident and their personal and material support and ii) operating procedures for providing care to victims of aircraft accidents and their relatives, including information, psychological, legal and financial aid, and their personal and material support. ${ }^{49}$

\subsection{Airport operator's liability}

According to directly applicable EU legislation on civil aviation security, ${ }^{50}$ an airport operator divides the airport area into individual sections according to the type of applied security measurements and marks them visibly. Under directly applicable

47 See Section 25 b of Act No 49/1997 on civil aviation amending Act No 455/1991 on trade business (Trade Act), as amended.

48 See Regulation (EU) No 996/2010 of the Europen Parliament and of the Council of 20 October 2010 on the investigation and prevention of accidents and incidents in civil aviation and repealing Directive $94 / 56 / \mathrm{EC}$.

49 See Section 68 of Act No 49/1997 on civil aviation amending Act No 455/1991 on trade business (Trade Act), as amended.

50 Regulation (EC) No 300/2008 of the European Parliament and of the Council of 11 March 2008 on common rules in the field of civil aviation security and repealing Regulation (EC) No 2320/2002. 
EU legislation on civil aviation security, the airport operator also ensures i) checking persons and vehicles entering the airport area, ii) issuing of airport identification cards and permits of entry into the aiport area, iii) screening of persons other than passengers and items carried, iv) airport area security. ${ }^{51}$

\section{Air carriage liability under European Union law}

\subsection{Regulation on air carrier liability in the event of accidents ${ }^{52}$}

Limits set on liability by the Warsaw Convention are too low by today's economic and social standards and often lead to lengthy legal actions which damage the image of air transport. As a result Member States have variously increased the liability limit, leading to different terms and conditions of carriage in the internal aviation market. In addition, the Warsaw Convention applies only to international transport, therefore distinction between national and international transport has been eliminated in the internal aviation market. It is appropriate to have the same level and nature of liability in both national and international transport.

After the adoption of the Montreal Convention by the Member States of the EU, an amended Regulation implements the relevant provisions of the Montreal Convention in respect of carriage of passengers and their baggage by air and lays down certain supplementary provisions. It also extends the application of these provisions to carriage by air within a single Member State. ${ }^{53}$ An air carrier does not mean every air transport, but only air carriage companies for the purpose of this Regulation. ${ }^{54}$

A supplementary sum which, in accordance with Article 22(2) of the Montreal Convention, ${ }^{55}$ may be demanded by an EU air carrier when a passenger makes a special declaration of interest in delivery of his baggage at destination, is based on a tariff which is related to the additional costs involved in transporting and insuring the baggage concerned over and above those for baggage valued at or below the liability limit. The tariff is made available to passengers on request. ${ }^{56}$

51 See Section 85n of Act No 49/1997 on civil aviation amending Act No 455/1991 on trade business (Trade Act), as amended.

52 Council Regulation (EC) No 2027/97 of 9 October 1997 on air carrier liability in the event of accidents, as amended by Regulation (EC) No 889/2002 of the European Parliament and of the Council of 13 May 2002. Available at: https://eur-lex.europa.eu/legal-content/EN/ALL/?uri=celex:32002R0889

53 See Art. 1 of Regulation (EC) No 2027/97, as amended by Regulation (EC) No 889/2002.

54 GIEMULLA, E. M. a L. WEBER. International and EU Aviation Law. Selected Issues. Alphen aan den Rijn: Wolters Kluwer International, 2011, p. 344.

55 Limits of liability in relation to delay, baggage and cargo.

56 See Art. 3a of Regulation (EC) No 2027/97, as amended by Regulation (EC) No 889/2002. 
The EU air carrier must without delay, and in any event not later than fifteen days after the identity of the natural person entitled to compensation has been established, make such advance payments as may be required to meet immediate economic needs on a basis proportional to the hardship suffered. An advance payment cannot be less than the equivalent in euro of 16000 SDR $^{57}$ per passanger in the event of death. An advance payment does not constitute recognition of liability and may be offset against any subsequent sums paid on the basis of EU air carrier liability, but is not returnable, except in cases prescribed in Article 20 of the Montreal Convention ${ }^{58}$ or in circumstances where it is subsequently proved that the person who received the advance payment was not the person entitled to compensation. ${ }^{59}$

All air carriers must, when selling carriage by air in the EU, ensure that a summary of the main provisions governing liability for passengers and their baggage, including deadlines for filing an action for compensation and the possibility of making a special declaration for baggage, is made available to passengers at all points of sale, including sale by telephone and via the Internet. In order to comply with this information requirement, EU air carriers use the notice contained in the Annex. Such summary or notice cannot be used as a basis for a claim for compensation, nor to interpret the provisions of this Regulation or the Montreal Convention.

In addition to the information requirements, all air carriers must in respect of carriage by air provided or purchased in the EU provide each passenger with a written indication of: i) the applicable limit for that flight on the carrier's liability in respect of death or injury, if such a limit exists, ii) the applicable limit for that flight on the carrier's liability in respect of destruction, loss of or damage to baggage and a warning that baggage greater in value than this figure should be brought to the airline's attention at check-in or fully insured by the passenger prior to travel, iii) the applicable limit for that flight on the carrier's liability for damage occasioned by delay.

In case of all carriage performed by EU air carriers, the limits indicated in accordance with the information requirements are those established by this Regulation unless the EU air carrier applies higher limits by way of voluntary undertaking. In case of all carriage performed by non-EU air carriers, the applicable limits on liability apply only in relation to carriage to, from or within the EU. ${ }^{60}$

There are no financial limits to liability for injury or death of a passenger. For damages up to 100000 SDRs (approximate amount in local currency) the air carrier cannot

57 Special Drawing Rights, SDR. A monetary unit of account used by the International Monetary Fund. SDRs are derived from average value of currency: U.S. Dollar $(0,58252)$, Euro $(0,38671)$, Chinese Yuan (1,0174), Japanese Yen (11,900), Pound Sterling (0,085946). 1 SDR = 1,37 USD (30/8/2019).

\footnotetext{
58 Exoneration.

59 See Art. 5 of Regulation (EC) No 2027/97, as amended by Regulation (EC) No 889/2002.

60 See Art. 6 of Regulation (EC) No 2027/97, as amended by Regulation (EC) No 889/2002.
} 
contest claims for compensation. Above that amount, the air carrier can defend itself against a claim by proving that it was not negligent or otherwise at fault. If a passenger is killed or injured, the air carrier must make an advance payment, to cover immediate economic needs, within 15 days from the identification of the person entitled to compensation. In the event of death, this advance payment cannot be less than 16000 SDRs (approximate amount in local currency).

In case of passenger delay, the air carrier is liable for damage unless it took all reasonable measures to avoid the damage or it was impossible to take such measures. Liability for passenger delay is limited to 4150 SDRs (approximate amount in local currency). In case of baggage delay, the air carrier is liable for damage unless it took all reasonable measures to avoid the damage or it was impossible to take such measures. Liability for baggage delay is limited to 1000 SDRs (approximate amount in local currency).

The air carrier is liable for destruction, loss or damage to baggage up to 1000 SDRs (approximate amount in local currency). In the case of checked baggage, it is liable even if not at fault, unless the baggage was defective. In the case of unchecked baggage, the carrier is liable only if at fault. A passenger can benefit from a higher liability limit for baggage by making a special declaration at the latest at check-in and by paying a supplementary fee. If the baggage is damaged, delayed, lost or destroyed, the passenger must write and complain to the air carrier as soon as possible. In case of damage to checked baggage, the passenger must write and complain within seven days, and in case of delay within 21 days, in both cases from the date on which the baggage was placed at the passenger's disposal.

If the air carrier actually performing the flight is not the same as the contracting air carrier, the passenger has the right to address a complaint or to make a claim for damages against either. If the name or code of an air carrier is indicated on the ticket, that air carrier is the contracting air carrier. Any action in court to claim damages must be brought within two years from the date of arrival of the aircraft, or from the date on which the aircraft ought to have arrived. ${ }^{61}$

\subsection{Regulation establishing common rules on compensation and assistance to passengers in the event of denied boarding and of cancellation or long delay of flights ${ }^{62}$}

While Council Regulation (EEC) No 295/91 of 4 February 1991 establishing common rules for a denied boarding compensation system in scheduled air transport ${ }^{63}$

\footnotetext{
61 See Annex to Regulation (EC) No 2027/97, as amended by Regulation (EC) No 889/2002.

62 Regulation (EC) No 261/2004 of the European Parliament and of the Council of 11 February 2004 establishing common rules on compensation and assistance to passengers in the event of denied boarding and of cancellation or long delay of flights, and repealing Regulation (EEC) No 295/91. Available at: https://eur-lex.europa.eu/legal-content/EN/TXT/?uri=CELEX:32004R0261

63 See Official Journal L 36, 8/2/1991, p. 5.
} 
created basic protection for passengers, the number of passengers denied boarding against their will remained too high, as did that affected by cancellations without prior warning and that affected by long delays. Therefore an effort is made to raise the standards of protection set by the aforementioned Regulation both to strengthen the rights of passengers and to ensure that air carriers operate under harmonised conditions in a liberalised market. Since the distinction between scheduled and non-scheduled air services is weakening, such protection should apply to passengers not only on scheduled but also on non-scheduled flights, ${ }^{64}$ including those forming part of package tours. The protection accorded to passengers departing from an airport located in a Member State is extended to those leaving an airport located in a third country for one situated in a Member State, when an EU carrier operates the flight.

The Regulation was more precisely interpreted by the judgement in the Schenkel Case (C-173/07). In this instance a booked return flight was cancelled by a carrier. However, the carrier refused to reimburse a passenger under the Regulation on the grounds that it is not an EU carrier and the return journey cannot be considered as a one flight from and to the same place, but it must be considered as two different flights. The Court ruled in the judgement that the concept of 'flight' within the meaning of the Regulation must be interpreted as consisting essentially in air transport operation, being as it were a 'unit' of such transport, performed by an air carrier which fixes its itinerary. The fact that these operations were booked at the same time within the same journey is not relevant. By contrast, the concept of 'journey' attaches to the person of the passenger, who chooses his destination and makes his way there by means of flights operated by air carriers. A journey, which normally comprises 'outward' and 'return' legs, is determined above all by the personal and individual purpose of travelling. ${ }^{65}$

As under the Montreal Convention, obligations of operating air carriers should be limited or excluded if an event has been caused by extraordinary circumstances which could not have been avoided even if all reasonable measures had been taken. Such circumstances may, in particular, occur in cases of political instability, meteorological conditions incompatible with operation of the flight concerned, security risks, unexpected flight safety shortcomings and strikes that affect operation of an operating air carrier. Extraordinary circumstances should be deemed to exist where the impact of an air traffic management decision in relation to a particular aircraft on a particular day gives rise to a long delay, an overnight delay, or the cancellation of one or more flights by that

64 GIEMULLA, WEBER, op. cit., p. 345.

65 See Judgement of the Court (Fourth Chamber) of 10 July 2008 in Case C-173/07, reference for a preliminary ruling under Article $234 \mathrm{EC}$ by the Oberlandesgericht Frankfurt am Main (Germany), made by decision of 7 March 2007, received at the Court on 2 April 2007, in the proceedings Emirates Airlines Direktion für Deutschland v Diether Schenkel.

Available at: http://curia.europa.eu/juris/document/document.jsf?text=\&docid $=67587 \&$ pageIn$\operatorname{dex}=0$ \& doclang $=\mathrm{EN} \& \operatorname{mode}=1 \mathrm{st} \& \mathrm{dir}=\& \operatorname{cocc}=$ first $\&$ part $=1 \& \mathrm{cid}=10731296$ 
aircraft, even though all reasonable measures had been taken by the air carrier concerned to avoid the delays or cancellations.

\subsubsection{Denied boarding}

The Regulation establishes, under the conditions specified herein, minimum rights for passengers when: i) they are denied boarding against their will; ii) their flight is cancelled; iii) their flight is delayed. ${ }^{66}$ Denied boarding means refusal to carry passengers on a flight, although they have presented themselves for boarding under stated conditions, except where there are reasonable grounds to deny them boarding, such as i) reasons of health, ii) safety or security, or iii) inadequate travel documentation. ${ }^{67}$

The Regulation applies: i) to passengers departing from an airport located in the territory of a Member State; ii) to passengers departing from an airport located in a third country to an airport situated in the territory of a Member State to which the Treaty applies, unless they received benefits or compensation and were given assistance in that third country, if the operating air carrier of the flight concerned is an EU carrier, on the condition that passengers: i) have a confirmed reservation on the flight concerned and, except in the case of cancellation, present themselves for check-in, as stipulated and at the time indicated in advance and in writing (including by electronic means) by the air carrier, the tour operator or an authorized travel agent, or, if no time is indicated, not later than 45 minutes before the published departure time; or ii) have been transferred by an air carrier or tour operator from the flight for which they held a reservation to another flight, irrespective of the reason.

The Regulation does not apply to passengers travelling free of charge or at a reduced fare not available directly or indirectly to the public. However, it applies to passengers having

66 See. Art. 1 of Regulation (ES) No 261/2004. The Regulation is applied to Gibraltar airport without affecting the respective legal positions of the Kingdom of Spain and the United Kingdom of Great Britain and Nothern Ireland with regard to the dispute over sovereignty over the territory in which the airport is situated. The application of the Regulation to Gibraltar airport shall be suspended until the arrangements in the Joint Declaration made by the Foreign Ministers of the Kingdom of Spain and the United Kingdom on 2 December 1987 enter into operation. The Governments of Spain and the United Kingdom will inform the Council of such date of entry into operation.

67 See Art. 2(j) of Regulation (ES) No 261/2004.

See e.g. Judgement of the Court (Third Chamber) of 4 October 2012 in Case C-22/11, reference for a preliminary ruling under Article 267 TFEU from the Korkein oikeus (Finland), made by decision of 13 January 2011, received at the Court on 17 January 2011, in the proceedings Finnair Oyj $v$ Timy Lassooy, and Judgement of the Court (Third Chamber) of 4 October 2012 in case C-321/11, reference for a preliminary ruling under Article 267 TFEU from the Juzgado de lo Mercantil No 2, A Coruña (Spain), made by decision of 29 March 2011, received at the Court on 28 June 2011, in the proceedings Germán Rodríguez Cachafeiro, María de los Reyes Martinez-Reboredo Varela-Villamorv Iberia, Lineas Aéreas de España SA.

Available at:

http://curia.europa.eu/juris/document/document.jsf?docid=128005 \& doclang=en

$\mathrm{http} / /$ curia.europa.eu/juris/document/document.jsf?docid=128002 \& doclang=EN 
tickets issued under a frequent flyer programme or other commercial programme by an air carrier or tour operator. The Regulation only applies to passengers transported by motorised fixed wing aircraft. ${ }^{68}$ Where an operating air carrier which has no contract with the passenger performs obligations under this Regulation, it is regarded as doing so on behalf of the person having a contract with that passenger. The Regulation does not affect the rights of passengers under Directive 90/314/EEC. ${ }^{69}$ This Regulation does not apply in cases where a package tour is cancelled for reasons other than cancellation of the flight. ${ }^{70}$ When an operating air carrier reasonably expects to deny boarding on a flight, it shall first call for volunteers to surrender their reservations in exchange for benefits under conditions to be agreed between the passenger concerned and the operating air carrier. Volunteers are to be assisted (right to reimbursement or re-routing) apart from the benefits. If an insufficient number of volunteers comes forward to allow the remaining passengers with reservations to board the flight, the operating air carrier may then deny boarding to passengers against their will. If boarding is denied to passengers against their will, the operating air carrier will immediately compensate them in accordance with this Regulation and assist them in accordance with the Articles (right to reimbursement or re-routing and right to care).$^{71}$

\subsubsection{Cancellation of a flight ${ }^{72}$}

Cancellation means a non-operation of a flight which was previously planned and on which at least one place was reserved. ${ }^{73}$ In case of cancellation of a flight: i) the passengers concerned are offered assistance by the operating air carrier (right to reimbursement or re-routing, meals and refreshments in a reasonable relation to the waiting time and free of charge two telephone calls, telex or fax messages, or e-mails) and in event of re-routing when the reasonably expected time of departure of the new flight is at least the day after the departure as it was planned for the cancelled flight, assistance (hotel accommodation in cases where a stay of one or more nights becomes necessary, or where a stay additional to that intended by the passenger becomes necessary; transport between the airport and place of accommodation); ii) the passengers concerned have the right to compensation by the operating air carrier if a) they are not informed of the cancellation at least two weeks before the scheduled time of departure, or b) they are not informed of the cancellation between two weeks and seven days before the scheduled time of departure and are not offered re-routing, allowing them to depart

\footnotetext{
68 The Regulation does not apply to carriage of persons by helicopters.

69 Council Directive of 13 June 1990 on package travel, package holidays and package tours (90/314/EHS).

70 Art. 3 of Regulation (ES) No 261/2004.

71 Art. 4 of Regulation (ES) No 261/2004.

72 Art. 5 of Regulation (ES) No 261/2004.

73 Art. 2(l) of Regulation (ES) No 261/2004.
} 
no more than two hours before the scheduled time of departure and to reach their final destination less than four hours after the scheduled time of arrival, or c) they are not informed of the cancellation less than seven days before the scheduled time of departure and are not offered re-routing, allowing them to depart no more than one hour before the scheduled time of departure and to reach their final destination less than two hours after the scheduled time of arrival.

When passengers are informed of the cancellation, an explanation must be given concerning possible alternative transport. An operating air carrier is not obliged to pay compensation (right to compensation), if it can prove that the cancellation is caused by extraordinary circumstances ${ }^{74}$ which could not have been avoided even if all reasonable measures had been taken. ${ }^{75}$ The burden of proof concerning the questions as to whether and when the passenger has been informed of the cancellation of the flight rests with the operating air carrier.

\subsubsection{Significant delay of a flight ${ }^{76}$}

When an operating air carrier reasonably expects a flight to be delayed beyond its scheduled time of departure: a) for two hours or more in the case of flights of 1500 kilometres or less, or b) for three hours or more in the case of all intra-EU flights of more than 1500 kilometres and of all other flights between 1500 and 3500 kilometres, or c) for four hours or more in the case of all flights not falling under a) or b), passengers must be offered by the operating air carrier: i) assistance (meals and refreshments in a reasonable relation to the waiting time and free of charge two telephone calls, telex or fax messages, or e-mails), or ii) assistance when the reasonably expected time of departure is at least the day after the time of departure previously announced (hotel accommodation in cases where a stay of one or more nights becomes necessary, or where a stay additional to that intended by the passenger becomes necessary; transport between the airport and place of accommodation), or iii) assistance when the delay is at least five hours

74 Extraordinary circumstances may, in particular, occur in cases of political instability, meteorological conditions incompatible with operation of the flight concerned, security risks, unexpected flight safety shortcomings and strikes that affect operation of an operating air carrier. (See Recital 14 in the preamble to Regulation No 261/2004.)

75 A reason of liberation. See e.g. Judgement of the Court (Third Chamber) of 31 January 2013 in Case C-12/11, request for a preliminary ruling under Article 267 TFEU from the Dublin Metropolitan District Court (Ireland), made by decision of 10 November 2010, received at the Court on 10 January 2011, in the proceedings Denise McDonagh v Ryanair Ltd.

Available at: https://eur-lex.europa.eu/legal-content/EN/TXT/?uri=CELEX\%3A62011CJ0012

76 See Art. 6 of Regulation (ES) No 261/2004.

See Judgement of the Court (Fourth Chamber) of 19 November 2009 (references for preliminary rulings from the Bundesgerichtshof (Germany) and the Handelsgericht Wien (Austria)) - Christopher Sturgeon, Gabriel Sturgeon, Alana Sturgeon, (C-402/07), Stefan Böck, Cornelia Lepuschitz (C-432/07) v Condor Flugdienst GmbH (C-402/07), Air France SA (C-432/07) (Joined Cases C-402/07 and C-432/07).

Available at: https://eur-lex.europa.eu/legal-content/EN/TXT/?uri=CELEX\%3A62007CJ0402 
(reimbursement within seven days of the full cost of the ticket at the price at which it was bought, in cash, by electronic bank transfer, bank orders or bank cheques or, with the signed agreement of the passenger, in travel vouchers and/or other services, for the part or parts of the journey not made, and for the part or parts already made if the flight is no longer serving any purpose in relation to the passenger's original travel plan, together with, when relevant, a return flight to the first point of departure, at the earliest opportunity). In any event, the assistance must be offered within the time limits set out above with respect to each distance bracket.

\subsubsection{Right to compensation ${ }^{77}$}

Passengers receive compensation (right to compensation) amounting to: a) EUR 250 for all flights of 1500 kilometres or less; b) EUR 400 for all intra-EU flights of more than 1500 kilometres, and for all other flights between 1500 and 3500 kilometres; c) EUR 600 for all flights not falling under a) or b). In determining the distance, the basis shall be the last destination at which the denial of boarding or cancellation will delay the passenger's arrival after the scheduled time. When passengers are offered re-routing to their final destination, the operating air carrier may reduce the compensation by $50 \%$, if the arrival time of the alternative flight does not exceed the scheduled arrival time of the flight originally booked: a) by two hours, in respect of all flights of 1500 kilometres or less, or b) by three hours, in respect of all intra-EU flights of more than 1500 kilometres and for all other flights between 1500 and 3500 kilometres, or c) by four hours, in respect of all flights not falling under a) or b). The compensation is to be paid in cash, by electronic bank transfer, bank orders or bank cheques or, with the signed agreement of the passenger, in travel vouchers or other services. The distances are measured by the great circle $^{78}$ route method. ${ }^{79}$

77 See Art. 7 of Regulation (ES) No 261/2004. See e.g. Judgement of the Court (Grand Chamber) of 23 October 2012 in Joined Cases C581/10 and C629/10, references for a preliminary ruling under Article 267 TFEU from the Amtsgericht Köln (Germany) and the High Court of Justice of England and Wales, Queen's Bench Division (Administrative Court) (United Kingdom), made by decisions of 3 November and 10 August 2010 respectively, received at the Court on 13 and 24 December 2010, in the proceedings Emeka Nelson, Bill Chinazo Nelson, Brian Cheimerie Nelson v Deutsche Lufthansa AG (C581/10), and The Queen, on the application of: TUI Travel plc, British Airways plc, easyJet Airline Company Ltd, International Air Transport Association v Civil Aviation Authority (C629/10).

Available at: https://eur-lex.europa.eu/legal-content/EN/TXT/?uri=CELEX\%3A62010CJ0581

78 The great-circle distance or orthodromic distance (from greek orthos - straight, dromos - a road) is the shortest distance between two points on the surface of a sphere.

79 Arrival time is considered to be the moment when the first aicraft door is opened and passengers are permitted to disembark the aircraft. See Judgement of the Court (Ninth Chamber) of 4 September 2014 in Case C-452/13, request for a preliminary ruling under Article 267 TFEU from the Landesgericht Salzburg (Austria), made by decision of 31 July 2013, received at the Court on 12 August 2013, in the proceedings Germanwings GmbH v Ronny Henning.

Available at: http://curia.europa.eu/juris/document/document.jsf?text $=\&$ docid $=157348 \&$ pageIn dex $=0 \&$ doclang $=\mathrm{EN} \&$ mode $=1$ st $\&$ dir $=\&$ occ $=$ first $\&$ part $=1 \& \mathrm{cid}=10735260$ 


\subsubsection{Right to reimbursement or re-routing ${ }^{80}$}

Passengers are offered the choice between: a) reimbursement within seven days of the full cost of the ticket at the price at which it was bought, for the part or parts of the journey not made, and for the part or parts already made if the flight is no longer serving any purpose in relation to the passenger's original travel plan, together with, when relevant, a return flight to the first point of departure, at the earliest opportunity; b) re-routing, under comparable transport conditions, to their final destination at the earliest opportunity; or c) re-routing, under comparable transport conditions, to their final destination at a later date at the passenger's convenience, subject to availability of seats. When, in the case where a town, city or region is served by several airports, an operating air carrier offers a passenger a flight to an airport alternative to that for which the booking was made, the operating air carrier bears the cost of transferring the passenger from that alternative airport either to that for which the booking was made, or to another close-by destination agreed with the passenger.

\subsubsection{Upgrading and downgrading ${ }^{81}$}

If an operating air carrier places a passenger in a class higher than that for which the ticket was purchased, it may not request any supplementary payment. If an operating air carrier places a passenger in a class lower than that for which the ticket was purchased, it must within seven days, in cash, by electronic bank transfer, bank orders or bank cheques or, with the signed agreement of the passenger, in travel vouchers or other services, reimburse a) $30 \%$ of the price of the ticket for all flights of 1500 kilometres or less, or b) $50 \%$ of the price of the ticket for all intra-EU flights of more than 1500 kilometres, except flights between the European territory of the Member States and the French overseas departments, and for all other flights between 1500 and 3500 kilometres, or c) $75 \%$ of the price of the ticket for all flights not falling under a) or b), including flights between the European territory of the Member States and the French overseas departments.

\subsubsection{Exclusion of waiver ${ }^{82}$}

Obligations vis-à-vis passengers pursuant to this Regulation may not be limited or waived, notably by a derogation or restrictive clause in the contract of carriage. If, nevertheless, such a derogation or restrictive clause is applied in respect of a passenger, or if the passenger is not correctly informed of his rights and for that reason has accepted compensation which is inferior to that provided for in this Regulation, the passenger is still entitled to take the necessary proceedings before the competent courts or bodies in order to obtain additional compensation.

\footnotetext{
80 Art. 8 of Regulation (ES) No 261/2004.

81 Art. 10 of Regulation (ES) No 261/2004.

82 Art. 15 of Regulation (ES) No 261/2004.
} 


\section{Air carriage liability under international law}

\subsection{Air carriage liability under the Montreal Convention ${ }^{83}$}

The Conference on Air Law to modernise the Warsaw System (air carrier liability) took place from 10 to 28 May in Montreal. The Convention, adopted at the Conference, modernizes and consolidates the 70-year-old system of legal instruments of Private International Law known as the „Warsaw System“ into a single document. The Convention is also meant to replace a number of combinations of carrier liability systems, established either by individual states, or by governmental or non-governmental organizations. Currently it has been ratified by 136 parties. ${ }^{84}$ The Convention entered into force on 4 November 2003.

The Convention establishes two tiers of compensation for victims of aircraft accidents. ${ }^{85}$ While in case of injury or death of a passenger the original Warsaw Convention included

83 Notification of the Ministry for Foreign Affairs No 123/2003 of conclusion of Convention for the Unification of Certain Rules Relating to International Carriage by Air. In accordance with Art. 55 of the Montreal Convention, this Convention prevails over any rules which apply to international carriage by air: 1. between States Parties to this Convention by virtue of those States commonly being Party to (a) the Convention for the Unification of Certain Rules Relating to International Carriage by Air signed at Warsaw on 12 October 1929 (hereinafter called the „Warsaw Convention“); (b) the Protocol to Amend the Convention for the Unification of Certain Rules Relating to International Carriage by Air Signed at Warsaw on 12 October 1929, done at The Hague on 28 September 1955 (hereinafter called The Hague Protocol); (c) the Convention, Supplementary to the Warsaw Convention, for the Unification of Certain Rules Relating to International Carriage by Air Performed by a Person Other than the Contracting Carrier, signed at Guadalajara on 18 September 1961 (hereinafter called the Guadalajara Convention); (d) the Protocol to Amend the Convention for the Unification of Certain Rules Relating to International Carriage by Air Signed at Warsaw on 12 October 1929 as Amended by the Protocol Done at The Hague on 28 September 1955 signed at Guatemala City on 8 March 1971 (hereinafter called the Guatemala City Protocol); (e) Additional Protocol Nos 1 to 3 and Montreal Protocol No 4 to amend the Warsaw Convention as amended by The Hague Protocol or the Warsaw Convention as amended by both The Hague Protocol and the Guatemala City Protocol signed at Montreal on 25 September 1975 (hereinafter called the Montreal Protocols); or 2. within the territory of any single State Party to this Convention by virtue of that State being Party to one or more of the instruments referred to in subparagraphs (a) to (e) above.

84 Available at: http://www.icao.int/secretariat/legal/List\%20of\%20Parties/Mtl99_EN.pdf

85 An accident means an unexpected or unusual event or situation independent of an passenger, similarly as in the Warsaw Convention amended in The Hague in 1955 (see Judgement in Case Saks v Air France). Not every unexpected or unusual event or situation is an accident, even though it causes injury or death (see Judgement of the District Court for the Southern District of Florida in Case Vanderwall v. United Airlines - slipping on a piece of garbage in the isle of an aircraft). Not every individual reaction of a passenger is an accident during a normal flight (see Judgement of the Supreme Court of the USA in Case Olympic Airways v. Husain - death as a result of an asthma attack triggered by smoke from a smoking section of the aircraft)

Available at:

http://www.gpo.gov/fdsys/pkg/USCOURTS-flsd-0_14-cv-60256/pdf/USCOURTS-flsd0_14-cv-60256-0.pdf

https://www.law.cornell.edu/supct/html/02-1348.ZS.html 
a limit of 125000 francs and the Hague Protocol (to which the Czech Republic is a contracting party as well) adjusted the limit up to 250000 francs, the new Convention establishes two tiers of liability. The first tier includes strict carrier's liability up to 100000 SDRs, regardless of whether the accident is due to the fault of the carrier or not. The second tier of liability is based on the presumed fault of the carrier and has no limit of liability. In case of delay the limit is 4150 SDRs for each passenger. The limit of 1000 SDRs was adopted for destroyed, lost or damaged baggage and 17 Special Drawing Rights is the limit per one kilogramme of cargo.

There is a new element of making advance payments to enable victims or persons entitled to compensation to cover their immediate economic needs. The amount of such advance payment depends on national law and is offset against any amounts subsequently paid as damages. Article 50 of the Convention establishes a right of the States Parties to require their carriers to maintain adequate insurance covering their liability under this Convention and also the State may require that a foreign carrier flying or intending to fly into that State furnishes evidence that it maintains adequate insurance covering its liability under this Convention. The Convention includes apart from the four existing jurisdictions the „fifth jurisdiction." Under certain circumstances in the event of bodily injury or death of a passenger the passenger or the person entitled can bring an action in the territory of a State Party in which at the time of the accident the passenger has his or her principal and permanent residence. The nationality of the passenger is not the crucial factor in this regard.

The Article 24 of the Montreal Convention provides for a mechanism of review of limits at five-year intervals in relation to an increase of inflation. The last adjustment of the limits took place in 2009. The revised limits, effective as of 30 December 2009, are: i) 19 SDRs per kilogramme in case of destruction, loss, damage or delay in relation to the carriage of cargo (Article 22, paragraph 3 of the Convention), ii) 1131 SDRs for each passenger in case of destruction, loss, damage or delay with respect to baggage (Article 22, paragraph 2 of the Convention), iii) 4694 SDRs for each passenger in relation to damage caused by delay in the carriage of persons (Article 22, paragraph 1 of the Convention) and iv) $113100 \mathrm{SDRs}$ for each passenger for damage sustained in case of death or bodily injury of a passenger (for the first tier) (Article 21, paragraph 1 of the Convention).

The adopted document is a result of compromises between a conception of the most advanced states (which would prefer to remove any liability limitations) and one of the poorer states (which would, on the contrary, welcome a lower limit of carrier liability). It can be stated that a balance was reached between the needs and interests of all participants in international air transport, i.e. travelling public and the air carriers. ${ }^{86}$

86 See the Parliament of the Czech Republic, Chamber of Deputies, 2000, Print of the Chamber No 528/0, Convention on Rules for International Carriage by Air.

Available in Czech: http://www.psp.cz/sqw/text/tiskt.sqw?O $=3$ \& CT $=528$ \& CT1 $=0$ 
According to the Montreal Convention, international carriage means any carriage in which, according to the agreement between the parties, the place of departure and the place of destination, whether or not there be a break in the carriage or a transhipment, are situated either within the territories of two States Parties, or within the territory of a single State Party if there is an agreed stopping place within the territory of another State, even if that State is not a State Party. Carriage between two points within the territory of a single State Party without an agreed stopping place within the territory of another State is not international carriage for the purposes of this Convention. ${ }^{87}$

\subsubsection{Carrier liability for death and injury of passengers and damage to baggage $e^{88}$}

Carrier liability for death and injury of passengers and damage to baggage almost copies a similar provision of the Warsaw Convention, amended by the Hague Protocol in $1955 .{ }^{89}$ The carrier is liable for damage sustained in case of death or bodily injury of a passenger upon condition only that the accident which caused the death or injury took place i) on board the aircraft, or ii) in the course of any of the operations of embarking or disembarking. The carrier is liable for damage sustained in case of i) destruction, or ii) loss of, or iii) of damage to, checked baggage (meaning baggage in the charge of the carrier) ${ }^{90}$ upon condition only that the event which caused the destruction, loss or damage took place on board the aircraft or during any period within which the checked baggage was in the charge of the carrier. ${ }^{91}$

However, the carrier is not liable if and to the extent that the damage resulted from the inherent defect, quality or vice of the baggage. ${ }^{92}$ In case of unchecked baggage (meaning baggage in the charge of the passenger), including personal items, the carrier is liable if the damage resulted from its fault or that of its servants or agents. ${ }^{93}$

87 Art. 1(2) of the Montreal Convention.

88 Art. 17 of the Montreal Convention and Art. 17 of the Warsaw Convention as amended at the Hague 1955. The phrasing ,death or wounding of a passenger or any other bodily injury “was changed to ,death or bodily injury of a passenger."

89 DEMPSEY, P. S. Accidents \& Injuries in Air Law: The Clash of the Titans. McGill University, p. 2. Available at: http://www.mcgill.ca/iasl/files/iasl/Titans.pdf

90 Since a moment when a passenger hands baggage over to an employee of the carrier to a moment when the passenger takes baggage back from a conveyor belt.

91 An air carrier is liable for damage upon conditions of: i) a loss event on board the aircraft, during any operation while embarking or disembarking, or during time checked baggage was in the charge of the carrier, delay of a flight, ii) strict liability of the carrier (under the Convention) and iii) causal link. A causal link is considered to exist in a situation when on the basis of an accident on the board of an aircraft, subsequently psychic trauma appears which results in injury or death of a passenger (Court of Appeals of the State of New York in Case Rosman v. Trans World Airlines). This perspective is applicable in relation to the Warsaw Convention amended in The Hague in 1955 and also to the Montreal Convention.

92 A reason of liberation.

93 It is liability based on fault, the passenger must prove fault of the carrier. 
If the carrier admits the loss of the checked baggage, or if the checked baggage has not arrived at the expiration of twenty-one days after the date on which it ought to have arrived, the passenger is entitled to enforce against the carrier the rights which flow from the contract of carriage.

\subsubsection{Carrier liability for damage to cargo $^{94}$}

The carrier is liable for damage sustained in the event of the destruction or loss of, or damage to, cargo upon condition only that the event which caused the damage so sustained took place during the carriage by air. However, the carrier is not liable if and to the extent it proves that the destruction, or loss of, or damage to, the cargo resulted from one or more of the following: i) inherent defect, quality or vice of that cargo; ii) defective packing of that cargo performed by a person other than the carrier or its servants or agents; iii) an act of war or an armed conflict; iv) an act of public authority carried out in connection with the entry, exit or transit of the cargo. ${ }^{95}$

The carriage by air within the said meaning comprises the period during which the cargo is in the charge of the carrier. The period of the carriage by air does not extend to any carriage by land, by sea or by inland waterway performed outside an airport. If, however, such carriage takes place in the performance of a contract for carriage by air, for the purpose of loading, delivery or transhipment, any damage is presumed, subject to proof to the contrary, to have been the result of an event which took place during the carriage by air. If a carrier, without the consent of the consignor, substitutes carriage by another mode of transport for the whole or part of a carriage intended by the agreement between the parties to be carriage by air, such carriage by another mode of transport is deemed to be within the period of carriage by air. ${ }^{96}$

\subsubsection{Carrier liability for delay ${ }^{97}$}

The carrier is liable for damage occasioned by delay in the carriage by air of passengers, baggage or cargo. Nevertheless, the carrier is not be liable for damage occasioned by delay if it proves that i) it and its servants and agents took all measures that could

94 Art. 18 of the Montreal Convention. It is based on the Montreal Protocol No. 4.

95 Reasons of liberation. The burden of proof rests with the carrier. A consignor, a consignee or another authorized person must prove the real amout of damage.

96 It is auxiliary carriage (loading, delivery or reloading) connected tho the door-to-door service.

97 Art. 19 of the Montreal Convention.

Delay means untimely time of arrival. Untimely time of arrival means that a moment at which all operations concerning a passenger disembarking from an aircraft or baggage and cargo delivery to the consignee does not correspond with scheduled time of carriage. Baggage is not considered to be late in the event of it arriving in a delayed flight together with the passenger. Non-operation of carriage happens in a situation when carriage does not commence at all or is not finished. In that case the victim must claim damages under national law (a contract of carriage was breached). 
reasonably be required to avoid the damage, or ii) that it was impossible for it or them to take such measures. ${ }^{98}$

\subsubsection{Exoneration from carrier liability ${ }^{99}$}

If the carrier proves that the damage was caused or contributed to by the negligence or other wrongful act or omission of the person claiming compensation, or the person from whom he or she derives his or her rights, the carrier is wholly or partly exonerated from its liability to the claimant to the extent that such negligence or wrongful act or omission caused or contributed to the damage. ${ }^{100}$ When by reason of death or injury of a passenger compensation is claimed by a person other than the passenger, the carrier is likewise to be wholly or partly exonerated from its liability to the extent that it proves that the damage was caused or contributed to by the negligence or other wrongful act or omission of that passenger. ${ }^{101}$

\subsubsection{Compensation in case of death or injury ${ }^{102}$ of passengers ${ }^{103}$}

For damages not exceeding $113100 \mathrm{SDR}^{104}$ for each passenger, the carrier is not able to exclude its liability (a first tier of strict liability). The carrier is not liable for damages to the extent that they exceed for each passenger 113100 SDR (a second tier of liability) if the carrier proves that: i) such damage was not due to the negligence or other

98 It is about presumed fault and proving proper care.

The District Court for the Eastern District of New York stated that a carrier cannot be liable for delay of a passenger caused by passport control officers in Case Edem v. Ethiopian Airlines Enterprise. A carrier is also not liable in case of a passenger not presenting himself for check-in at a check-in desk after repeated call, after which the carrier offered the cancelled seat of thus delayed passenger to passengers without reservation (,stand-by“) - see Judgement of the District Court for the Northern District of Texas in Case Igwe v. Northwest Airlines.

Available at:

https://casetext.com/case/edem-v-ethiopian-airlines-enterprise

http://www.gpo.gov/fdsys/pkg/USCOURTS-txsd-4_05-cv-01423/pdf/USCOURTS-txsd4_05-cv-01423-0.pdf

99 Art. 20 of the Montreal Convention.

100 A reason of liberation. The burden of proof rests with the carrier. A consignor, a consignee or another authorized person must prove the real amout of damage.

101 A reason of liberation as well.

102 An injury can be: i) physical (a fracture), ii) psychological (trauma caused by turbulence), iii) physical caused by psychological (sexual harassment leading to trichotillomania) and iv) psychological caused by physical (depression from inability to move as a result of an injury).

103 Art. 21 of the Montreal Convention.

104 For the State Parties which are not Members of the International Monetary Fund, the conversion of the SDRs into national currencies is set out in Article 23 of the Montreal Convention. 
wrongful act or omission of the carrier or its servants or agents; or ii) such damage was solely due to the negligence or other wrongful act or omission of a third party. ${ }^{105}$

\subsubsection{Limits of liability in relation to delay, baggage and cargo ${ }^{106}$}

In case of damage caused by delay in the carriage of persons, ${ }^{107}$ the liability of the carrier for each passenger is limited to 4694 SDR. In the carriage of baggage, the liability of the carrier in the case of destruction, loss, damage or delay is limited to 1131 SDR for each passenger unless the passenger has made, at the time when the checked baggage was handed over to the carrier, a special declaration of interest in delivery at destination and has paid a supplementary sum if the case so requires. In that case the carrier will be liable to pay a sum not exceeding the declared sum, unless it proves that the sum is greater than the passenger's actual interest in delivery at destination.

In the carriage of cargo, the liability of the carrier in case of destruction, loss, damage or delay is limited to a sum of 19 SDR per kilogram, ${ }^{108}$ unless the consignor has made, at the time when the package was handed over to the carrier, a special declaration of interest in delivery at destination and has paid a supplementary sum if the case so requires. In that case the carrier will be liable to pay a sum not exceeding the declared sum, unless it proves that the sum is greater than the consignor's actual interest in delivery at destination. In case of destruction, loss, damage or delay of part of the cargo, or of any object contained therein, the weight to be taken into consideration in determining the amount to which the carrier's liability is limited shall be only the total weight of the package or packages concerned. Nevertheless, when the destruction, loss, damage or delay of a part of the cargo, or of an object contained therein, affects the value of other packages covered by the same air waybill, or the same receipt or, if they were not issued, by the same record preserved by the other means, the total weight of such package or packages will also be taken into consideration in determining the limit of liability. ${ }^{109}$

105 The Court of Appeal for England and Wales ruled that slipping is a risk of ordinary life and a carrier is not liable for it in Barclay v. British Airways.

Available at: https://www.lambchambers.co.uk/news-and-resources/barclay-v-british-airways-plc.htm 106 Art. 22 of the Montreal Convention.

107 A liability limitation for damage caused by delay in carriage of persons was newly integrated. The Guatemala City Protocol served as an inspiration.

Damage may be interpreted to include or not to include psychological injury caused by delay. EU courts usually grant damages for psychological injury (apart from the British), the Americans do not.

108 Liability of a carrier for cargo is strict and of an unbreacheable limit.

109 The Court of Justice of the EU has a right to interpret the Montreal Convention, because the EU is a contracting party (see Council Decision No 2001/539/EC). Therefore, the CJEU ruled in Axel Walz v. Click air SA (case C-63/09) that the term „damage“, which underpins Article 22(2) of the Convention for the Unification of Certain Rules for International Carriage by Air, concluded in Montreal on 28 May 1999, that sets the limit of an air carrier's liability for the damage resulting, inter alia, from the loss of baggage, must be interpreted as including both material and non-material damage.

Available at: http://curia.europa.eu/juris/document/document.jsf?text=\&docid=81177 \& pageIn$\mathrm{dex}=0$ \& doclang $=\mathrm{EN} \&$ mode $=$ lst $\&$ dir $=\&$ occ $=$ first $\&$ part $=1 \&$ cid $=10752327$ 
The foregoing provisions (concerning damage caused by delay in the carriage of persons and in the carriage of baggage) are not applied if it is proved that the damage resulted from an act or omission of the carrier, its servants or agents, done with intent to cause damage or recklessly and with knowledge that damage would probably result; provided that, in case of such act or omission of a servant or agent, it is also proved that such servant or agent was acting within the scope of its employment. ${ }^{110}$

The aforementioned limits of liability do not prevent the court from awarding, in accordance with its own law, in addition, the whole or part of the court costs and of the other expenses of the litigation incurred by the plaintiff, including interest. This provision does not apply if the amount of the damages awarded, excluding court costs and other expenses of the litigation, does not exceed the sum which the carrier has offered in writing to the plaintiff within a period of six months from the date of the occurrence causing the damage, or before the commencement of theaction, if that is later.

\section{Conclusion}

The aim of this treatise is to analyze the current legal environment regulating air carrier liability in the carriage of passengers, baggage and cargo. In international air transport, we can consider the Montreal Convention for the Unification of Certain Rules for International Carriage by Air as the most important, replacing the existing chaotic Warsaw System (the Warsaw Convention for the Unification of Certain Rules Relating to the International Carriage by Air, amended by the Hague Protocol and the Guadalajara Convention), which is still in effect in relation to the states which have not ratified the Montreal Convention. In fact, there are two exising legal systems governing international air carriage still remaining.

The Warsaw Convention established a carrier liability system for the first time, a carrier is liable in case of injury or death of passengers, damage or loss of baggage and cargo and for damage caused by delay in carriage. Other international documents were adopted, co-creating the Warsaw System along with the Warsaw Convention, but these international instruments have not received equal support. Some states have become contracting parties to various documents. Therefore, several liability systems existed simultaneously.

110 There is a mistake in the Czech translation of the Montreal Convention, a given condition of liability is constructed as ,it is not proven that... was acting within the scope of its employment." Compare to the English version: „provided that... was acting within the scope of its employment. "There is not negation, of course.

In case of damage caused by delay in the carriage of cargo the liability limitation is not breached. A carrier is liable without limits concerning passengers and baggage, if the victim proves that damage was caused by the carrier with intent or negligence. 
The modernization of liability provisions is the principal contribution of the Montreal Convention, i.e. particularly the introduction of the system of two tiers of liability in the event of death or injury of passengers, the fifth jurisdiction and a periodical review of limits at five-year intervals. The system of the Montreal Convention originates from the Warsaw Convention and assumes many categories from the Warsaw System, but the Montreal Convention attempts to make the terminology more precise and to reflect progress. Unfortunately, the Convention does not address regulation of carrier liability for immaterial damage. The text includes many concepts, which may lead to incorrect application, but fortunately the courts interpret them in a similar manner to how the terms were interpreted while applying the Warsaw Convention. The Czech translation of the Montreal Convention contains cardinal inaccuracies in provisions about the fifth jurisdiction and a condition of an aircraft to be leased or owned by the carrier itself and of premises leased or owned by the carrier itself. The Montreal Convention takes precedence over any other Warsaw System treaties for the contracting parties. However, it does not impose an obligation on the contracting parties to denounce these other treaties after ratification of the Montreal Convention.

Regarding carrier liability for damage, the Montreal Convention is complemented by Regulation No 2027/97 on air carrier liability in the event of accidents, amended by Regulation No 889/2002, and Regulation No 261/2004 establishing common rules on compensation and assistance to passengers in the event of denied boarding and of cancellation or long delay of flights. This Regulation strenghtens the passengers's rights significantly, but it brings disproportionate costs to the carriers sometimes. The Court of Justice of the EU has concluded that the Montreal Convention (the $\mathrm{EU}$ is a contracting party) does not prohibit further specifications of rights and obligations of the parties to a carriage contract. The Regulation No 2027/97 lost its purpose with the adoption of the Montreal Convention by all of the EU Member States and was amended by the Regulation No 889/2002 to serve as an implementing and supplementary provision of the Montreal Convention in EU air carriage.

Particular types of contract in the field of carriage and liability for damage are regulated by the Czech Civil Code. 